371.3::811.163.41

811.163.41'35

https://doi.org/10.18485/kij.2020.67.1.12

САША С. ЧОРБОЛОКОВИЋ *

Основна школа ,3. октобар”

Бор
Оригинални научни рад

Примљен: 26.04.2020.

Прихваћен: 05.06.2020.

\title{
КРЕАТИВНА НАСТАВА ПРАВОПИСА У ОСНОВНОЈ ШКОЛИ ${ }^{* *}$
}

\begin{abstract}
У раду се разматра креативна настава правописа у основној школи. Основни циљ рада је представити успешне креативне примере из наставне праксе (стрипови, графити, мајице, граничници, изложба). Задаци рада су показати како се све може реализовати креативна настава правописа у старијим разредима основне школе (као наставна или ваннаставна активност, радионица, пројектна настава), затим указати на све њене специфичности и предности у односу на традиционалну наставу, као и на другачију, измењену улогу и наставника и ученика у савременом наставном процесу. Креативна настава правописа доприноси учењу правописних правила с разумевањем, појачаној мотивисаности ученика за рад, већој трајности и функционалности знања из правописа, као и развоју критичког мишљења.
\end{abstract}

Кључне речи: правопис, креативност, српски језик, настава, методика.

\section{1. Увод}

Један од циљева предмета Српски језик и књижевност у основној школи је и поступно и систематично упознавање са ортографском нормом српског језика и оспособљавање ученика за њено правилно коришћење. Садашња настава правописа се, с друге стране, углавном заснива на учењу, препознавању и увежбавању нормативних правила путем правописних вежби. Примери често нису из непосредног окружења, нити су повезани са искуством ученика (нису им блиски и познати ${ }^{1}$ ) услед чега ученици имају пасивно знање правописа (знају прави-

*saleprof@gmail.com

** Овај рад је настао на основу истоимене радионице која је одржана 8. фебруара 2020. године у оквиру 61. Републичког зимског семинара за наставнике и професоре српског језика и књижевности на Филолошком факултету у Београду.

${ }^{1}$ Као један од недостатака садашње наставе правописа је непостојање добре конктекстуализације наставног садржаја..., јер знања из језика не ваља ослањати само на дефиниције и правила; 
ла, али доста греше или их не примењују). ${ }^{2}$ Ако знамо да тежиште савремене наставе правописа није на давању готових знања већ на искуственом учењу и активном стицању знања, подстицању стваралачких активности, проблем се усложњава и захтева промене у методама и техникама рада наставника, уопште у приступу и начину организовања наставе правописа у школи.

Полазећи од садашње наставне праксе и креативности као императива и темеља савремене школе, ${ }^{3}$ у раду се разматра креативна настава ${ }^{4}$ правописа у основној школи. Основни циљ рада је представити успешне креативне примере из наставне праксе (стрипови, графити, мајице, граничници, изложба) као својеврсну методичку стратегију за подстицање ученичке креативности у процесу усвајања правописних правила. Задаци рада су показати како се све може реализовати креативна настава правописа у старијим разредима основне школе (као наставна или ваннаставна активност, радионица, пројектна настава), затим указати на све њене специфичности и предности у односу на традиционалну наставу, као и на измењену улогу и наставника и ученика у њој.

\section{2. Правопис у приручничкој, методичкој и уџбеничкој литератури}

Правописни приручници правописну тематику обрађују на различите начине. Најраширенији начин представља разјашњење одређених недоумица и најчешћих правописних грешака прецизним и јасним научним стилом (Стијовић 2009; Телебак 2011; Новокмет/Слијепчевић/Николић 2016; Бјелаковић 2017). То је заправо интерпретација и појашњење параграфа актуелног правописа. Понекад оваква објашњења постају део новинских рубрика као одговор читаоцима који су писали и тражили разјашњење стручњака (Фекете 2008) или су сегмент радио-емисија (Блажић 2015). Поред тога има и оних приручника који правопис презентују кроз наративне сегменте: конкретне дијалошке ситуације из свакодневног живота. На тај начин истиче се важност примене правописа у свакој комуникативној ситуацији, а истовремено и показује српски језик у реалном контексту (Бабић 2014, Блажић 2015). У новије време јављају се стрипови са правописним примерима (Јокановић 2019) и школски правописни речници

много је боље и ефикасније утемељити их на конкретним, занимљивим и лако памтљивим ситуацијама, јер ће тако брже постати активна (Вељковић Станковић 2010: 10)”.

${ }^{2}$ У прилог томе иде и резултат кратке анализе основних података на вежбанкама из Српског језика и књижевности ученика петог разреда борске ОШ „3. октобар”. Наиме, од укупно 105 вежбанки чак 80 (76,19 \%) садржало је неку грешку у писању назива школе, наставног предмета, разреда и одељења, школске године, па све до погрешног места уписивања потребних података.

${ }^{3}$ Међу бројним теоријама креативне наставе, посебно се истичу стране теорије Лава Виготског и Жана Пијажеа. Овом темом код нас су се бавили и Радивој Квашчев, Милан Баковљев и Марко Стевановић. О историјату креативне наставе в. шире у Маринковић 2000: 14-16.

${ }^{4}$ Маринковић (2000: 17) креативну наставу дефинише као наставу „која за своје кључно одређење узима афирмацију стваралаштва ученика и наставника у васпитно-образовном процесу”. 
(Вујовић 2018). Реално процењујући, у сваком приручнику се може пронаћи понешто, ни у једном све, а по неком неписаном правилу може се десити да баш кад се нешто тражи, одговор изостане, или их пак буде више, што ствара додатну конфузију. ${ }^{5}$

У уџбеничкој литератури, уочљив је двојак начин презентовања градива из правописа: као посебан одељак о правопису (Новокмет/Ђорђевић/Златић 2019: 166-181; Ломпар 2019: 96-106), или после одређеног дела градива из језика (Слијепчевић/Станковић Шошо/Сувајџић 2019; Милићевић/Ракоњац Николов 2019). Понекад се примери одређених огрешења у пракси издвајају и у посебно насловљеним деловима типа Пажюа (Ломпар 2019), Обрати пажъу (Слијепчевић/Станковић Шошо/Сувајџић 2019), Како се пише (Новокмет/Ђорђевић/Златић 2019), Запамти и ово (Срдић 2012), Језичке смицалице (Милићевић/Ракоњац Николов 2019) и сл. Међутим, дистрибуција правописних садржаја у уџбеницима ${ }^{6}$ не спутава наставнике да направе сопствени распоред градива у свом плану рада и да сами осмисле најефикаснији начин обраде или утврђивања у настави.

Репрезентативна методичка литература углавном предлаже правописне вежбе за усвајање и увежбавање правописних правила (Николић 2006: 770-797; Илић 2006: 566-570). Међутим, нису све описане вежбе заживеле у наставној пракси. Много је више предлога методичара у односу на дате примере у приручницима за наставнике и уопште конкретну примену на часовима. Заједничко за све примере је одсуство креативности. Акценат је на усвајању, увежбавању неке правописне теме, тј. правила, а не на откривању, подстицању стваралачких потенцијала сваког ученика и оспособљавању за примену правописа у свакој ситуацији.

\section{3. Креативни предлози наставе правописа у наставној пракси}

Настава правописа се може значајно иновирати уколико се наставне јединице планирају и реализују на другачији начин. Стрипови, граничници, мајице, изложба, правописна јелка, дрво, загонетка, графити су само неки предлози којима се утврђује или обрађује градиво из правописа (одређена правописна правила, недоумице и грешке), али и подстиче креативност ученика. Сви примери су својеврсни путоказ за оне који желе да их примене у настави било у истом или модификованом облику.

${ }^{5}$ И у самом Правопису 2010 има доста изузетака, много дублетних решења, нормативни критеријуми нису увек довољно јасни, па се уместо учења правила, врло често прибегава учењу појединачних примера. Све то умногоме отежава примену ортографске норме.

${ }^{6}$ Правописне лекције у уџбеницима врло су значајне јер важећи Правопис 2010 нема своје школско издање. Ако знамо да је очекивани исход који ученик у петом разреду треба да оствари користити правопис (школско издање), остаје нејасно како то у пракси спровести, тј. како да ученик научи/ зна да користи нешто чега нема. Брборић 2019: 64 наводи две могућности као решење постојећег проблема: приредити ново школско издање или прогласити приручник Милорада Дешића (Дешић 2015) званичним школским издањем. 


\section{Правописни стрипови}

Стрип $^{7}$ као кратка ликовно-литерарна форма (вербо-визуелни медијум) може бити врло ефектно и ефикасно средство у наставном процесу, нарочито уколико се тематски и контекстуално повеже са школским животом. Јунаци и ситуације блиске деци, занимљиви кратки хумористички дијалози уписани у облачиће могу бити корисни и за учење, усвајање нових или утврђивање већ обрађених наставних садржаја. Иако је у досадашњој наставној пракси, стрип био чешћи у књижевности (нпр. најпознатији су стрипови Ђорђа Лобачева), стрип се може користити и у правопису: као најава одређене правописне теме, као врло функционална илустрација или пример одређеног правописног правила. Стрипови илуструју добру међупредметну корелацију (Српски језик и Ликовна култура) јер комбинују текст и слику. Једном осмишљени, најуспешнији стрипови се могу користити и као наставно средство више пута. Стрип се може користити на више начина: 1) ученици могу осмислити и нацртати цео стрип, 2) ученици цртају стрип на основу датог текста, 3) ученици смишљају текст и убацују у облачиће већ нацртаног стрипа.

\section{Слика 1 и 2: Правописни стрипови}
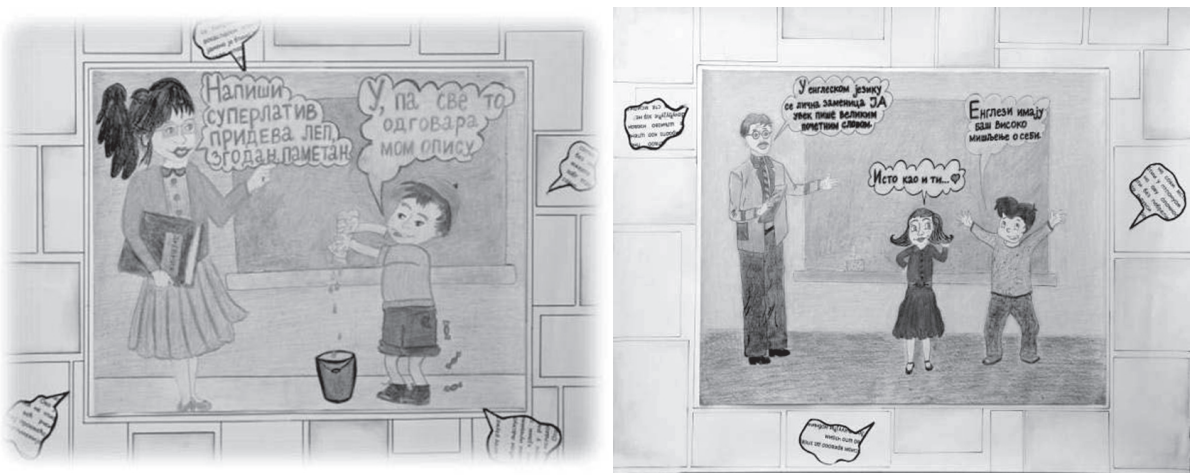

Правописна јелка/дрво

Задаци алтернативног избора су данас врло чести. Они захтевају процену тачности одређеног исказа, одређеног примера или избора између две могућности које се међусобно искључују. Понекад се још и зову да/не или тачно/нетачно питања. Као један од начина онеобичавања ових питања, а појачавања заинтересованости за учење и активно учешће на часу јесте њихово стављање

${ }^{7}$ О пореклу и значају стрипа и неким примерима употребе в. Драмац/Лазарич 2016 и Лазарич, 2013. и Дејановић 2018. Дејановић (2018) је са својим ученицима осмислио и издао збирку Да ти нацртам, збирку едукативних стрипова, који су настали на часовима Српског језика, Ликовне културе, у оквиру слободних активности и на радионицама посвећеним стварању стрипа. Највећи број примера је из књижевности млађих разреда. Из језика су обрађени придеви и глас ј. 
у форму игре. Правописна јелка и правописно дрво су врло сврсисходне игре у утврђивању правописних правила и оспособљавању ученика за критичку процену примера у окружењу.

Новогодишње честитке (исправне и неисправне) исписане на украсима налазе се помешане у корпи на наставниковом столу. Сваки ученик извлачи по једну са задатком да је прочита, размисли и одговори да ли је правилно или неправилно написана. Уколико је честитка тачно написана, украс ће ставити на зелени део правописне јелке. Ако је честитка са неком грешком, ученик треба да је прво региструје, саопшти, исправи и на крају стави на црвени део јелке. Наставник све време прати, има улогу супервизора, некога ко ће контролисати ученичке одговоре. После сваког одговора ученик добија малу коверту са поруком (уколико је тачно проценио, добија слику Деда Мраза који држи подигнут прст, а уколико је дао нетачан одговор, наставник му даје коверат са сликом Деда Мраза са шаљивом поруком да ће за Нову годину добити правопис).

\section{Слика 3 и 4: Новогодишња јелка}

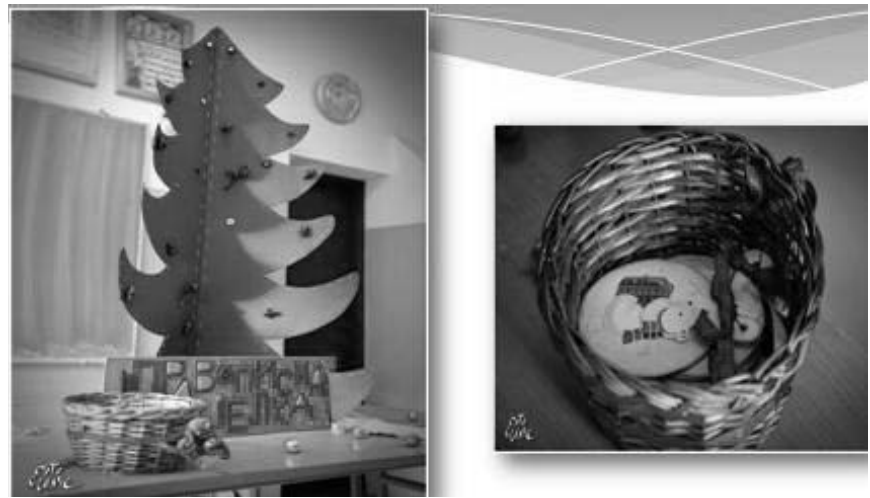

Два дрвета (дрво писмености и дрво неписмености) треба нацртати на посебним хамерима. Одштампане правилне и неправилне примере глаголских облика на листовима треба исецкати и помешати. Листови могу бити на наставниковом столу или у некој корпи. Задатак сваког ученика је да извуче један лист и процени да ли је глаголски облик на њему исправно написан или не. Уколико је тачно написан, треба да га обоји у зелено, а ако је неправилан у наранџасто/ браон, а потом и стави на одређено правописно дрво. Игра се завршава када се сви листови залепе. 


\section{Слика 5: Правописно дрво}

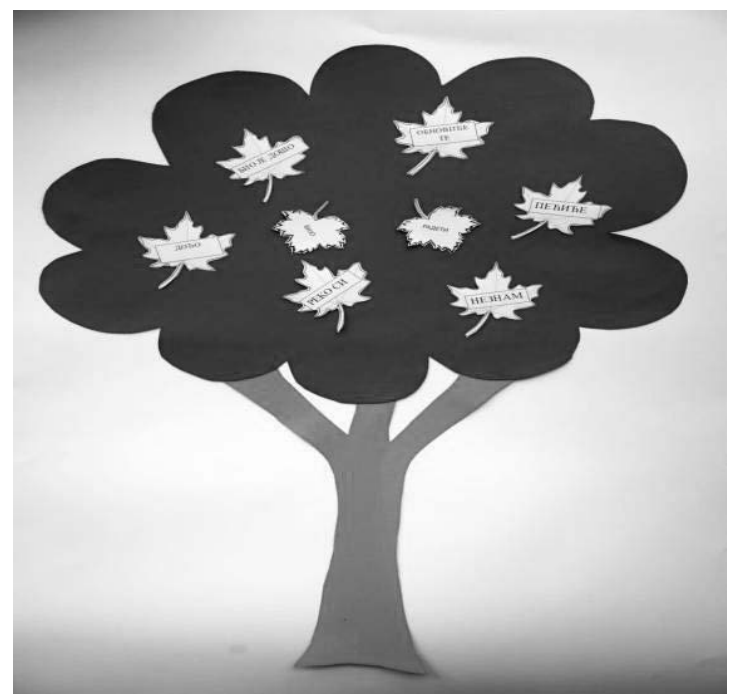

Правописна изложба

Витич, Шулер (1966: 136) истичу да наставна изложба треба да буде резултат заједничког планирања наставника и ученика. Она треба да одражава максимум ученичке иницијативе и стваралачког учешћа. Једна од таквих изложби је и изложба фотографија јавних натписа са правописном грешком. Оваква изложба привлачи ученике и побуђује мотивацију. Она је у исто време и мотивациона, али и развојна јер пружа могућности за развијање одговорности и свести о важности поштовања правописа, нарочито у јавном простору. У њеној припреми и реализацији има више фаза:

1. Расписивање фото-конкурса;

2. Фотографисање и слање примера електронском поштом;

3. Прегледање и анализа примера;

4. Заједнички задаци на припреми изложбе (план изложбе);

5. Уређивање изложбе;

6. Завршна наставна изложба (проглашење победника конкурса).

\section{Пример фото-изложбе Ма ко је бре неписмен!}

Прва фаза наставне изложбе ${ }^{8}$ био је фото-конкурс путем кога је прикупљено 95 фотографија јавних натписа са правописном грешком. На конкурсу су

\footnotetext{
${ }^{8}$ Правописна изложба се може реализовати и као пројектна настава.
} 
учествовале све борске основне школе. У другој фази грешке су анализиране и груписане по правописним областима (велико слово, писмо, интерпункција и транскрипција). У оквиру заједничких задатака на припреми изложбе прво је одређен наслов Ма ко је бре неписмен у коме је садржана основна идеја да правила без примене немају никакву вредност и важност, а потом се приступило визуелном представљању теме. Написане су кратке духовите дијалошке ситуације у вези са правописним темама у којима су регистроване најчешће грешке, извршен је избор глумаца, чланова драмске секције, који су добили задатак да науче (драматизују) текст, и на крају су снимљени и кратки видео-записи. Једна група ученика је изабрала мисли наших лингвиста о језику, које су прекуцане и убачене у посебно декорисане рамове. Чланови ликовне секције су осмислили граничнике за књиге са правописним правилима и мале коверте са по једним правописним правилом, које су посетиоци добили на изложби. Изабрани су и лапсуси и досетке ученика у вези са правописом, које су потом ученици обликовали у виду кратких стрипова. Финална фаза била је фото-изложба у борској Народној библиотеци, на којој су били проглашени победници конкурса.

\section{Правописна загонетка}

Задаци за вербално закључивање 9 још нису добили заслужено место у нашим збиркама задатака с обзиром на важност и значај који имају у многим страним образовним системима. Један од таквих типова задатака је и језичка загонетка. Онеобичавање језичких правила и питања кроз осмишљавање језичких загонетки ${ }^{10}$ значајна је иновација у настави језика. Језичке загонетке су ученицима занимљиве јер су другачије и по форми и по садржини питања која су традиционално заступљена током вежбања, утврђивања градива, па и у тестовима провере знања. Језичке загонетке треба одгонетнути. Да би се дошло до одговора, потребно је користити асоцијације и логичко размишљање јер нигде нема граматичких термина и уобичајеног радног захтева као у класичним питањима.

\footnotetext{
${ }^{9}$ Ломпар (2018) наводи да овакви задаци постоје у британском образовном систему. У њима нема граматичких термина. „Форма им је разноврсна и зависи од језичког нивоа и проблема на који се односе: могу бити у виду различитих врста словних допуњалки, преметаљки, укрштеница, затим у виду логичких проблема и кодирања речи итд. Разликују се, дакле, од уобичајених задатака у нашој наставној пракси - и по форми и по садржају (Ломпар 2018: 1). У самом раду постоје и бројни модели и примери за вежбање који могу бити подстицајни за стварање нових.

${ }^{10}$ Велики број загонетних прича постоји и у Ломпар 2014.
} 
Табела 1. Упоредни приказ правописног правила и правописне загонетке ${ }^{11}$

\begin{tabular}{|l|l|}
\hline \multicolumn{1}{|c|}{ Класично правило } & \multicolumn{1}{|c|}{ Језичка/правописна загонетка } \\
\hline $\begin{array}{l}\text { Речца не се уз именице, придеве и } \\
\text { прилоге пише спојено, а одвојено од } \\
\text { глагола. Једини изузеци су: нисам, } \\
\text { нећу, немој, немам. }\end{array}$ & Са именицама, придевима и прилозима \\
& Међу глаголима пријатеља је мало \\
& до њих ми није стало, нисам, нећу, \\
& готово да за њих немам воље немој \\
& ме питати зашто ми је без њих боље. \\
& Ко сам ја ${ }^{11}$ ? (Речца не). \\
\hline
\end{tabular}

\section{Правописни граничници}

Прављење граничника је постало уобичајено приликом интерпретације књижевних дела и издвајања лепих мисли, универзалних порука, уопште анализе идејног слоја. Ова активност може бити сврсисходна и у језику након обраде неког правописног правила ради његовог лакшег усвајања, и то као стваралачка активност у завршном делу часа. Могуће је осмислити и одређену тематску радионицу поводом обележавања неког значајног датума (нпр. Међународни дан писмености, Међународни дан матерњег језика...).

\section{Слика 6: Правописни граничниции}

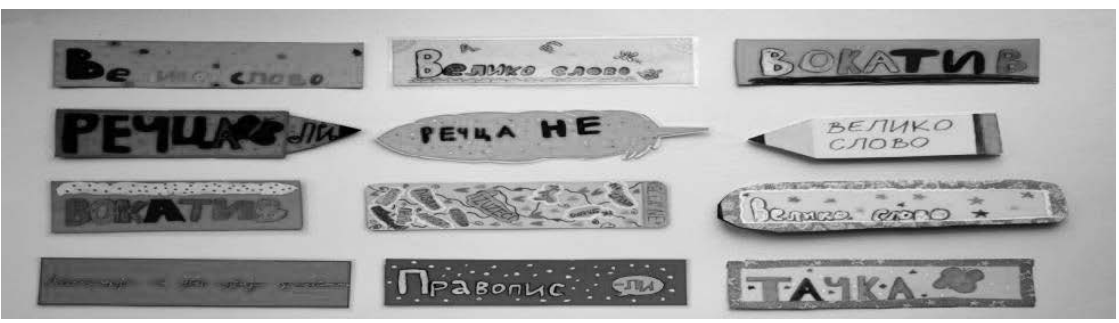

Правописни графити

Графити увек могу бити погодни за скретање пажње на неке учестале правописне грешке у писању, а све ради њиховог смањивања и временом искорењивања. Ученици могу добити задатак да осмисле цео графит или само његово визуелно решење на основу унапред припремљеног текста. На крају се од нају-

${ }^{11}$ Ова прича може имати и питање са понуђеним одговорима: а) речца не б) речца ли в) предлог са г) префикс нај-. 
спелијих радова може направити пано (налик зиду) у холу школе. Кроз ову активност истиче се таленат ученика и популарише правопис и његова примена (ортографска норма).

\section{Слика 7: Правописни графит}

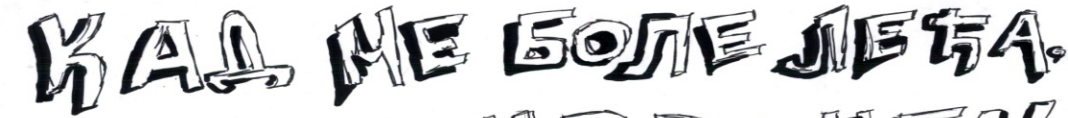

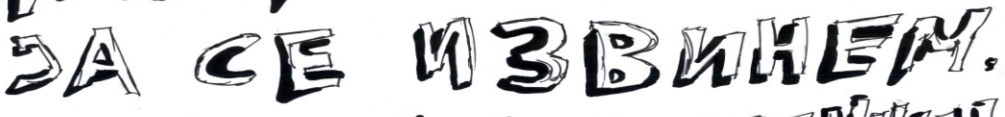 A r all 细 L 3 B B}

\section{Правописне мајице}

Будући да се данас врло често штампају разни натписи у виду кратких порука на мајицама (нарочито на крају школске године у осмом разреду), ову заинтересованост и креативност ученика у осмишљавању што оригиналнијег текста за мајицу можемо искористити и у настави правописа. Ученицима се може дати задатак да осмисле духовити натпис како би указали на неку учесталу правописну грешку. Ученици прво треба да нацртају и изрежу мајицу на картону, обоје је и креирани натпис испишу. ${ }^{12}$ Битно је да натпис буде упечатљив, видљив и са типичним правописним огрешењем. ${ }^{13}$

\footnotetext{
${ }^{12}$ Како би се задатак успешно завршио, ученицима (сваком пару) треба дати кратко упутство (основне инструкције за рад).

${ }^{13}$ Примери таквих огрешења огледају се у погрешном писању речца ли, не, префикса нај-, гласа $j$ или $x$, у стварању нових скраћеница које ученици користе у дописивању на друштвеним мрежама, затим у мешању ћирилице и латинице, употреби латинице са словима без дијакритичких знакова, изостављању или писању погрешних интерпункцијских знакова и сл. Приликом реализације овог часа, наставник мора правилно усмеравати ученике приликом избора примера и на време их кориговати да се не би десило да из незнања или неразмишљања издвоје и напишу неку грешку која није правописна: нпр. граматичку (погрешну употребу падежса, глаголског облика) или стилску (плеоназам, двосмисленост). Пожељно је и да примери буду разноврсни, да се не понављају и да осликавају реално стање: не измишљено или непостојеће, (нпр. нај ачи). Како би сваки пар завршио задатак, врло је важно пратити и временску артикулацију часа и повремено их подсећати колико им је времена остало за рад.
} 


\section{Слика 8 и 9: Правописне мајище}

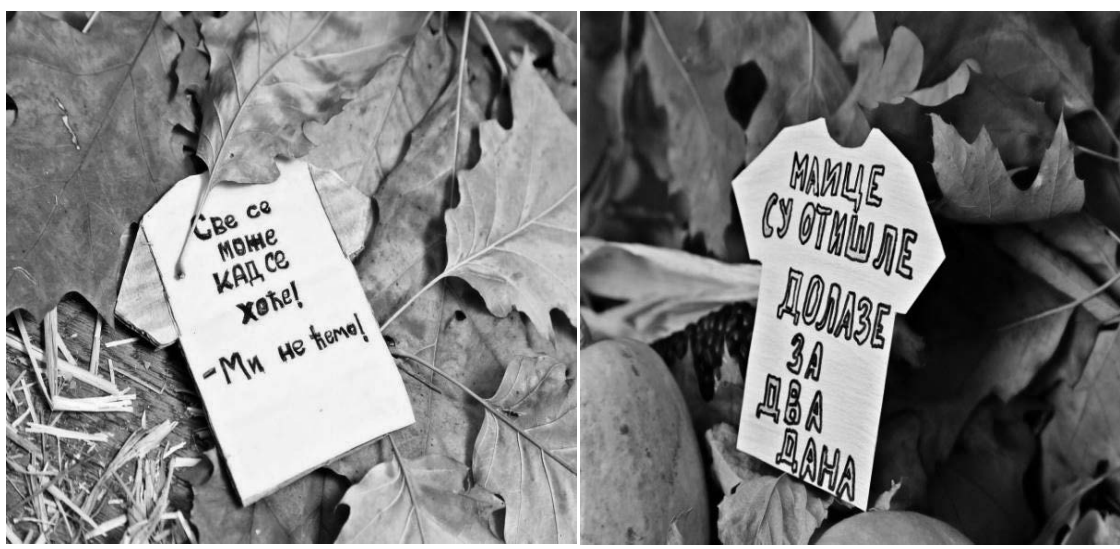

\section{4. Предности креативне наставе правописа}

Креативна настава правописа доприноси учењу с разумевањем, појачаној мотивисаности ученика за рад, већој трајности и функционалности знања из правописа и развоју критичког мишљења. Кроз продуктивно учење и самосталан рад, ученици треба да се заинтересују за правопис, науче не само основна правила него и да креативно и критички приступе решавању било ког правописног проблема.

Да би креативна настава правописа била успешно реализована, потребна је добра и пажљива припрема, која захтева време, одређени материјал за рад, добру процену временске динамике сваке активности јер уколико ју је немогуће временски уклопити у час редовне наставе, онда она мора бити део ваннаставних активности. Наставник мора бити добар методички стратег и неко ко ће добро проценити вероватноћу саме реализације у настави (Јоцић 2007: 64). У овако организованој настави, наставник није једини извор знања и ловац на грешке, већ партнер у учењу, неко ко ученике правилно усмерава и води до решења. Уз то и сами ученици могу да управљају својим процесом учења и преузму одговорност за сопствени напредак.

\section{5. Закључак}

У раду су представљени креативни примери наставе правописа (стрипови, граничници, графити, изложба, мајице). Описане активности су замишљене као својеврсна препорука за иновирање наставе правописа уз уобичајене правописне вежбе у настави. У њима су истакнута одређена правописна правила или одређене правописне грешке. Као што је и показано, реализација описаних активности је најчешћа на часовима редовне наставе: део часа (уводни, главни, 
завршни) или цео час. Такође, уколико активност захтева више времена, онда се она остварује као нека ваннаставна активност.

Наставник мора бити добар познавалац материје коју предаје, али и неко ко је креативно оријентисан, спреман да трага за другачијим техникама у раду јер у савременој настави није битно само шта се ради већ много више како се ради. Ученици кроз осмишљене активности уче да анализирају, критички размишљају, закључују, оспособљавају се да употребе своје знање и открију и развију своје стваралачке потенцијале, а не само да репродукују градиво. Услед свега тога много више се отварају могућности за развој међупредметних компетенција, а настава правописа добија нови квалитет - постаје стваралачка, игролика и истраживачка.

\section{АНАЛИЗИРАНИ УЏБЕНИЦИ}

Ломпар 2019: В. Ломпар, Граматика 5, Београд: Клет.

Милићевић/Ракоњац Николов 2019: Д. Милићевић и С. Ракоњац Николов, Граматика, Београд: Вулкан издаваштво.

Новокмет/Ђорђевић/Златић 2019: С. Новокмет, В. Ђорђевић, И. Златић, С речи на дела, Београд: Бигз.

Слијепчевић/Станковић Шошо/Сувајџић 2019: С. Слијепчевић, Н. Станковић Шошо, Б. Сувајџић, Језичко благо, Београд: Логос.

Срдић 2019: Ј. Срдић, Дар речи, Београд: Логос.

\section{ЛИТЕРАТУРА}

Бабић 2014: В: Бабић, 365 језичких иртица, Београд: Креативни центар.

Бјелаковић 2017: И . Бјелаковић, Реч по реч, Нови Сад: Два пера.

Блажић 2015: М. Блажић, Српски на српском, Београд; РТС.

Брборић 2019: В. Брборић, Однос основног Правописа српског језика и различитих правописних деривата, у: М. Ковачевић (ур.), Нови прилози српском правопису, Нови Сад: Матица српска и Вишеград: Андрићев институт, 51-65.

Вељковић Станковић 2010: Д. Вељковић Станковић, Комуникативни приступ у настави српског језика, Узданица VII/1, стр. 7-17.

Витич/Шулер 1966: В. Арно Витич и Ч. Франсис Шулер, Аудио-визуелна средства, Београд: Вук Караџић.

Вујовић 2018: Д. Вујовић, Језичке мозгалище, Нови Сад: Либер.

Дејановић 2018: М. Дејановић, Да ти нацртам, Врање: Удружење Живојин Мишић.

Дешић 2015: М. Дешић, Правопис српског језика (школско издање), Београд: Клет. 
Драмац/Лазарич 2016: I. Dramac i M. Lazzarich, Smješna strana obrazo-vanja - humor u poučavanju, Život $i$ škola, LXII/3, 87-97.

Илић 2006: П. Илић, Српски језик и књижевност у наставној теорији и пракси, Нови Сад: Змај.

Јокановић 2019: Б. Јокановић, 100 Сизифових правила, Београд: Вулкан издаваштво.

Јоцић 2007: 3. Јоцић, Језичко стваралаштво ученика у настави граматике, Београд: Учитељски факултет.

Ломпар 2017: В. Ломпар, Задаци који подразумевају тзв. вербално закључивање, Прилози настави српског језика и књижевности: часопис Друштва наставника српског језика и књижевности Републике Српске, 6, 83-95.

Ломпар 2014: В. Ломпар, Језичке главоломке, Београд: Клет.

Маринковић 2000: С. Маринковић, Методика креативне наставе српског језика и књижевности, Београд: Креативни центар.

Николић 2006: М. Николић, Методика наставе српског језика и књижевности, Београд: Завод за уџбенике и наставна средства.

Правопис 2010: М. Пешикан, Ј. Јерковић, М. Пижурица, Правопис сpncкога језика, измењено и допуњено издање (Мато Пижурица, Милорад Дешић, Бранислав Остојић, Живојин Станојчић), Нови Сад: Матица српска.

Слијепчевић/Новокмет/Николић 2016: С. Слијепчевић, С. Новокмет, М. Николић, Језикофил, Београд: Клет.

Стијовић 2009: Р. Стијовић, Норма и пракса, Београд: Завод за уџбенике.

Телебак 2011: М. Телебак, Како се каже, Нови Сад: Прометеј.

Фекете 2008: Е. Фекете, Језичке доумище, Београд: Београдска књига.

Saša S. Čorboloković

\section{CREATIVE TEACHING OF ORTHOGRAPHY IN ELEMENTARY SCHOOL}

\section{Summary}

This paper considers creative teaching of orthography in elementary school. The main aim of the paper is to present successful creative examples in teaching practice (comics, graffiti, tshirts, bookmarkers, exposition). The tasks of the paper are to show how creative teaching of orthography can be realized in higher grades of elementary school (as a curricular or extracurricular activity, workshop, project-based learning); then, to indicate all its particularities and advantagesin comparison to traditional teaching, as well as to show different, changed roles of 
both the teacher and the student in modern teaching process. Creative teaching of orthography contributes to learning the spelling rules with understanding, to better students' motivation, greater permanence and functionality of spelling knowledge, as well as the development of critical thinking.

Key words: orthography, creativity, Serbian language, teaching, methodology. 